\title{
3 Chosenness: supersessionism and racist anti-Judaism
}

The Hebrew Bible defines the people of Israel as God's chosen people. A strong tradition within Christianity has explained this status as being obsolete: the old covenant was replaced by the Gospel, circumcision by baptism, Sabbath by Sunday. Consequently, this tradition sees Christians as the chosen people and Jews as just as obsolete as their faith.

In nineteenth-century Sweden, several authors and publishers felt called upon to argue in print as to why the Jewish religion was not only obsolete but also wrong, dangerous, hostile to Christians, and the origin of Jews' sense of being special. The Jewish religion has been quite unique in its ability to maintain a varied but still unified religious identity, despite centuries of diaspora; it is difficult to say to what extent the actual experiences of diaspora communities and their ways of maintaining religious and cultural difference contributed to this Christian need to construct the Jewish minority as a closed, unchangeable, and hostile group adhering to an outdated set of rules.

Two sets of texts fed into the supersessionist discourse in the nineteenth century: several translated texts from German and British authors targeting Judaism as a religion, and a large number of writings dealing with conversion. The first category was clearly more significant in the first half of the century, basing itself on relatively recent text models, the oldest of which stemmed from the eighteenth century. The second category consisted of different varieties of text: Some are based on medieval text models and represent a "Protestant turn" regarding the role of miracles in conversion processes; these appear mainly in the first half of the century. Later, translations from Prussian Protestant texts appear alongside the growing Swedish revival movement and its productions. Finally, at the very end of the century, the Föreningen för Israelsmissionen, an organization founded just after Emancipation, was responsible for a sudden increase in the publication of conversion stories, many of which featured prominent lay preachers who had themselves converted from Judaism.

All of these different categories feature supersessionism and the perceived transfer of the status of chosenness from the Jewish people to Lutherans or Protestant revivalists, but they also combined this with other, mostly biologistic, categories of hostility.

Ә OpenAccess. ( $2022 \mathrm{He}$, published by De Gruyter. (cc) BY-NC-ND This work is licensed under the Creative Commons Attribution-NonCommercial-NoDerivatives 4.0 International License. 


\section{Lutheran miracles: Swedish conversion narratives}

The question of Jewish conversion to Christianity - how it could be brought about, how often it happened, how more of it might happen, and whether it would actually do anything to change the "Jewish character" - had been preoccupying the Christian mind for centuries. ${ }^{133}$ In Sweden, too, tales of Jewish conversion had been a popular genre since the Middle Ages. Exempla, sermons, and especially miracle tales connected to the Virgin Mary employed conversion narratives with a twofold purpose: first, to provide an example of faith for Christians (if they can come to the true faith, anybody can), and second, to say something about Jews in general. The narrative structure of these tales often involves a Jewish child, not yet corrupted and therefore open to the Gospel. The adversaries are the Jewish relatives, who oppose the conversion of their child, sometimes going so far as to engage in kidnapping or violence against the child. Other types of stories involve mass conversions brought about by preaching - whether this ever happened anywhere at any point in history remains unknown, but medieval towns, landlords, and theologians often fostered hopes in this regard, and would force entire Jewish communities to listen to Christian sermons. When their hopes failed to materialize, pogroms were a frequent consequence. ${ }^{134}$

Both of these types of narratives reappear in nineteenth-century Sweden. The publications were usually commissioned by one of the evangelical communities, missionary groups, or the like, but also by the Lutheran State Church. Their settings, structure, and plot had not changed much since the Middle Ages, even though they did not directly follow text models from the Old Swedish legendary or exempla collections. ${ }^{135}$ The most important examples are Fornsvenska legendariet and Själens tröst, the latter being a close adaptation of the Middle Low German Seelentrost. Jonathan Adams has identified the following typology of conversion stories in the medieval Nordic texts: miracles triggered by an act of violence against Christianity; a miracle triggered by Jewish disbelief; a miraculous act of healing; a feeling of anguish or despair upon witnessing a superna-

133 The research on medieval converts is vast and is focused on the Iberian Peninsula. See, for example: Kevin Ingram, The Conversos and Moriscos in Late Medieval Spain and Beyond, Brill ebooks v. 197 (Boston: Brill, 2009); Paola Tartakoff, "Christian Kings and Jewish Conversion in the Medieval Crown of Aragon,” Journal of Medieval Iberian Studies 3, no. 1 (2011).

134 See, for example: Jonathan Adams and Jussi Hanska, eds., The Jewish-Christian Encounter in Medieval Preaching, Routledge Research in Medieval Studies 6 (New York: Routledge, 2015). 135 For a comprehensive collection and discussion of the Old Danish and Old Swedish material on Jewish conversion, see Adams, Jews in East Norse Literature (forthcoming). 
tural phenomenon; persuasion through argumentation or disputation; a gentle spiritual awakening induced by the love of the Virgin Mary (with much overlapping between the different categories). In nineteenth-century Sweden, the Virgin Mary had lost her role as the main catalyst of Jewish conversion; especially when discussing child conversions, however, medieval text models (with Protestant adjustments) were still evoked. In many cases, the abstract Protestant concept of grace took her place, as was already prominent in the title of one of the bestselling conversion stories, Nådens verkan hos barn (The effect of grace on children), which was released in at least 15 editions between 1791 and $1826 .{ }^{136} \mathrm{Nå}$ dens verkan hos barn. Märkeligen wised uti följande twänne historier. Den första: om tre af judiska, den andra: om fyra af christna religionen groups the translation with a German anonymous edificatory story ${ }^{137}$ and a second story of unknown origin. The same year it came out in Elberfeld, Merkwürdige Bekehrungs-Geschichte was translated and printed by different publishing houses all over the country. The story deals with three daughters from a Jewish family, who meet Jesus while talking and praying with some Christian children. They approach a priest and convince him to set up a commission in order to ascertain whether they had been forced to convert and what role their parents, who were still Jewish, were to have in their lives, both then and in the future. After long and suspiciously detailed descriptions of the girls' testimonies and their parents' tears, the commission finds their conversion believable, takes them away from their parents, and lets them prepare to be baptized. They take Christian first names and the surname Hirtentreu (literally: loyal to the shepherd, i.e. Christ).

This story, thoroughly situated in a German Protestant context - the priests in the commission are named and their Lutheran and Reformed denominations are mentioned, as well as Hofprediger Kamann, the girls' teacher - breaks with the medieval traditions of child conversion narratives. There is no animosity between children and parents, and instead of quickly accepting the girls' conversion, the authorities point to the prohibition of their converting without their parents' consent. In contrast to the medieval narratives, this text does not connect the Christian faith to miraculous and sudden conversions, but rather to extended learning processes and to the inexplicable yet undeniable power of grace. The Protestant idea of predestination replaces the older plots in which good (Christian) wins over evil (Jewish); it is mentioned several times that God's grace

136 Anonymous, Nådens verkan hos barn. Märkeligen wised uti följande twänne historier. Den första: om tre af judiska, den andra: om fyra af christna religionen (Göteborg: Norberg, 1791); (Gävle: Ernst Peter Sundqvist, 1798). See the complete list of editions in the appendix.

137 Anonymous, Merkwürdige Bekehrungs-Geschichte dreyer Schwestern von acht, zehn und zwölf Jahren (Elberfeld: Giesen, 1791). 
and love also apply to Jewish children. Compared to the narratives that adhere to the medieval traditions, this story was probably popular for the ways in which it fostered a sense of authenticity: names and places are provided, authorities and regulations mentioned. Nothing miraculous needs to happen, and instead of being referred to as the Virgin, Mary is called Jesus's "foster mother."

An anonymous text from the Nya förlagsexpeditionen publishing house, promoted by Karl Erixon, who was active in missionary activities and Stockholm's town mission, told the story of the Jewish boy Majer, who was placed in a Christian school by his mother. ${ }^{138}$ Little Majer started singing Christian songs at home, to which his grandfather, "en gammal otrogen Israelit, som tyckte det wara något riktigt gräsligt att höra Jesu namn nämnas” (a real Israelite nonbeliever, who found it really horrible to hear the name of Jesus, p. 4), scolded him and his mother for the song and for bringing Jesus into a Jewish home. Subsequently, the boy suddenly fell ill with diphtheria and died a few days later, with the same Christian psalm on his lips. The text is described as a translation in the subtitle, but no source is immediately obvious - however, the narrative is similar to many others of its kind. Death and violence often befall the Jewish relatives, but in this version, the family is punished with the child's death. The characters in the text are modernized, as is the plot itself, but these remain Protestant versions of conversion stories, just without the help of a miracle: the boy who is able to see the truth of the Gospel after only being casually exposed to it, the evil family members trying to prevent the conversion, violence against the child, the punishment of the family. Similar details are present in the medieval legend "The Jewish boy in the oven," in which a Jewish father throws his son, who attended a Christian mass, into a fiery oven, where he is miraculously saved by the Virgin Mary. The story ends with the father being thrown into the oven and dying. The story is part of a long medieval tradition, in both the Latin and the Greek Church, and can be traced back to the biblical story of the three young men in the oven (Dan. 3). The medieval legendary versions mock this story in which three young Israelites refuse to worship the gods of Nebuchadnezzar.

That this story was printed by a publishing house closely connected to missionary activities and evangelical circles suggests that winning Jewish converts was only one part of its intended effect. Proselytizing to Jews and pagans ${ }^{139}$

138 Den lille judegossen som dog i tron på Jesus. Öfwersättning. Samt Det skall icke skada dig och Kom till Jesus, sång af G.W. (Stockholm: Nya Förlagsexpeditionen, 1876).

139 Missions amongst "pagan" peoples are not included in the corpus of anti-Jewish texts, but Swedish missionaries were active in such endeavours, for example, in colonies on the African 
was (and partly is) an important activity of revivalist movements, and their relation to Israel and the people of Israel, both contemporary and historical-biblical, is complicated. ${ }^{140}$ Many of the texts produced in this context follow medieval conversion-narrative traditions but also include accounts by Jewish converts to Protestant Christian denominations writing in the early modern period. Conversion - and not only from Judaism - was a much debated phenomenon in the early modern period, and the autobiographies of converts have taught historians much about the inner motivations that led people to seek to change their religion and social context. The narratives of Jewish converts, however, always also fulfil another purpose: to condemn Judaism as a religion. This is a trait shared by the more stereotypical narratives, which remain true to medieval narrative traditions, as well as the post-Reformation ones.

Lying somewhere in between medieval Catholic and modern Protestant conversion narratives is Karl Heinrich Caspari's Kristen och jude: en berättelse från 16:e århundradet. ${ }^{141}$ Caspari was a Lutheran theologian and author in France, ${ }^{142}$ his Christ und Jude came out in 1861 and was translated into Swedish six years later. Taking place in the 1560s, over 230 pages Caspari recounts a complicated story of a nobleman on his deathbed and a Jewish family with a father described negatively as "typically Jewish” and a good-looking son. The son argues with various Christians about the messiah and the Gospel but still fights on their side against the Turks. He then finally recognizes Jesus Christ as his saviour and is triumphantly led to his baptism. The novel contains all of the religious stereotypes Christians have concocted: Jews are blind, stubborn, and hostile to Christians, but still, some of them can see the truth and consequently are able to reject Judaism and change sides.

Forced preaching had acquired an important place in Swedish conversion narratives, due to the fact that there were actual Jews to preach to and that, since the mid-seventeenth century, conversion had been a requirement for Jews who wished to be allowed to stay in Sweden. Before the judereglemente al-

continent. See Pia Lundqvist, Ett motsägelsefullt möte: Svenska missionärer och Bakongo i Fristaten Kongo (Lund: Nordic Academic Press, 2018).

140 See David M. Gustafson, D. L. Moody and Swedes: Shaping Evangelical Identity Among Swedish Mission Friends, 1867-1899, Linköping Studies in Identity and Pluralism 7 (Linköping: Linköping University, Department of Culture and Communication, 2008). Regarding the American influences on Nya förlagsexpeditionen and their discussions about how to interpret scripture regarding the conversion of Jews and pagans, 157. Regarding Karl Erixon, 77.

141 Karl Heinrich Caspari, Kristen och jude: en berättelse från 16:e århundradet (Stockholm: Normans förlagsexp, 1867).

142 Gustav Leopold Plitt, “Caspari: Karl Heinrich C,” in Allgemeine Deutsche Biographie, vol. 4, 55 (Leipzig: Duncker \& Humblot, 1876). 
lowed Jews to immigrate and keep their faith, a number of immigrant families were baptized in Sweden. These occasions were marked by much pomp and ceremony celebrating the victory of Christianity, following the example of the first judedopet (Baptism of Jews) in 1681, when two families from France had converted. ${ }^{143}$ Even after 1782, the first generations of Jewish immigrants were often baptized or requested baptism for their children, in order to secure their access to society, education, and marriage. We usually lack accounts from the converts themselves; instead, a number of Christian writings deal with the topic. Compared to their medieval models, the Jews themselves are strangely absent from the Swedish texts: their deeds and actions do not provoke miracles or cause them to accept the Christian faith, their conversion comes only after the text or the narrated story itself. One typical example is a sermon by Anders Berg, a parish priest, who wrote Jesu dop med helig ande och med eld framställdt, wid en judisk ynglings döpelse in 1827. ${ }^{144}$ Despite the prominence of Jewish conversion in the title, the text itself is a general baptismal sermon, there is no explicit mention of Jewish religion except for the title and the address to the converted boy.

A British text was translated and disseminated in Sweden as early as 1807, celebrating an incident where Jews were forced to listen to a sermon by the popular preacher William Cooper from London. Cooper was a lay preacher, educated as a physician, who had written a dissertation on abortion. ${ }^{145}$ He performed a series of sermons in front of 500 Jews in Whitechapel in the summer and autumn of 1796, apparently convincing them to convert in large numbers. One of his most widely reproduced and distributed sermons, The Promised Seed, ${ }^{146}$ was translated into Swedish and published with a short introduction about Cooper and his success sermonizing to the Jews. It bore a seal from the cathedral chapter in

143 A copper engraving depicting the event can be seen at https://stockholmskallan.stockholm. se/post/28438. The Jewish Museum in Stockholm had a temporary exhibition featuring several locations associated with Jewish history in the city, including Tyska Kyrkan where the baptism took place. See https://judiskamuseet.se/utforska/traces-of-existence/det-stora-judedopet/det_ stora_judedopet/.

144 Anders Berg, Jesu dop med helig ande och med eld framställdt, wid en judisk ynglings döpelse ... Säljes till förmån för församlingens skola (Stockholm: Olof Grahn, 1827).

145 [William Cooper], Diss. ... inaug. de abortionibus (Lugduni: Bat., 1767). Attribution of the author by GBV.de.

146 William Cooper, The promised seed. A sermon preached to God's ancient Israel the Jews, at Sion-Chapel, Whitechapel. On Sunday afternoon, August 28, 1796 (Boston: Manning \& Loring, 1796). 
Visby, dated $1805,{ }^{147}$ thereby lending legitimacy from the State Church to the revivalist text. Cooper's sermon is not so much antisemitic as it is arrogant: it is a variation on the old Christian art of citing textual evidence from the Old Testament to prove that Jesus is the messiah and that Christians, even the unlearned, have a superior understanding of scriptural prophecies. Swedish readers must have been amazed at the power of the Gospel, when read to 500 Jewish listeners.

In the Swedish version, Cooper's sermon is distributed together with an anonymous text dealing with the same topic. Bref från en resande jude is a fictitious letter from a person travelling in Judea and Galilee during Jesus's lifetime and the period immediately after his death. He writes to a Rabbi Aron and tells him about his meeting with Jesus, the miracle of Lazarus, and other events. He is quite convinced that he has met the messiah, predicts great things to come for the rabbi, and promises further news about the deeds of the apostles. The editor of the letter simply states that its source is "Forntiden" (history), and leaves it to the reader to assess this. It is a close translation of a text by Johann Heinrich Jung-Stilling, another physician who turned to pietistic and mystical writings later in life. His Schreiben eines reisenden Juden aus der Vorzeit probably appeared the same year as the Swedish translation, and was translated into several Germanic languages and printed in chapbook form. Later, the text was also translated into Danish and Icelandic, and distributed in all the Nordic countries in Iceland, surprisingly enough, surviving in several manuscripts but not in any printed editions. ${ }^{148}$ While theologically not very innovative, the version containing Cooper's sermon and the Bref frän en resande jude lends official ecclesiastical authority to two rather obscure lay testimonies - and thus positions supersessionism as a legitimate feature of the Lutheran Church in Sweden.

What is more surprising is that the translator or editor did not mention the original author by name, given that Heinrich Jung-Stilling was at the time already well known and popular in Sweden, roughly 20 of his texts having been translated and published. Most of these were of a similar character to the Bref: open letters and tractates addressing a Christian public, calling for conversion, and predicting the impending victory of the Christian religion - the latter conceptualized as the Pietist form of Protestantism. The significance of this booklet in transmitting anti-Jewish thought lies in the grouping of the two texts: the sermon, which was so powerful that most of the Jewish listeners converted, and

147 William Cooper, Cooper's Prädikan för judarna, och et bref från en resande jude. Öfwersättning (Göteborg: Samuel Norberg, 1807).

148 The information on this in Wikipedia is comprehensive, but not verifiable from other, more reliable sources. https://en.wikipedia.org/wiki/Schreiben_eines_reisenden_Juden_aus_der_Vor zeit. 
the traveller from biblical times bearing witness to Jesus's miracles and writing about them to a rabbi. Together, these present a strong Augustinian argument of Jews being witnesses to Jesus as the messiah and, simultaneously, the necessity and possibility of converting them. The texts also add to the specific Jewish temporality constructed by Christians, using conversion to connect them through the centuries: the travelling Jew converts when he sees Jesus, the British Jews convert when they hear Cooper's sermon.

More theologically rigorous is the autobiography of a Dutch-Portuguese convert, Abraham Capadose, which was translated and printed in at least two editions, the second being published by Evangeliska forsterlands-stiftelsen, a revivalist organization within the State Church. ${ }^{149}$ Capadose, a physician, converted in 1822 at the age of 27 , subsequently becoming a writer and political activist. He wrote several books and pamphlets about his own conversion, some of them directed at his former Jewish co-religionists. The Swedish edition, which consists of 60 printed pages, does not include a separate preface, but starts with his account of his childhood in an assimilated non-religious Jewish family. He describes services during his childhood as empty, lacking veneration, chaotic, in a language most of the community did not understand. As a teenager, Capadose decided to become a "true Israelite," rejecting liberal Judaism out of "national pride" (p. 11). He then met Christ, and his family punished him for his decision to convert. The excerpt is followed by an afterword by the French editor, professor Pettavel of Neufchâtel, which discussed the two men's correspondence about Capadose's wife dying. Like many autobiographies of converts, Capadose expresses disgust regarding Jewish religious practices - a tradition inherited from Johannes Pfefferkorn and a long series of ethnographic writings about Judaism - as well as disappointment about his family's lack of understanding for his decision.

Another convert was David Baron, of Great Britain, who founded the Hebrew Christian Testimony to Israel missionary organization in London. His text The Jewish Problem - Its Solution or, Israel's Present and Future was first published in 1891, a translation being published eight years later. ${ }^{150}$ While Baron aimed at converting Jews to Hebrew Christianity, a Jewish sect, the text was published in Sweden by the Christian missionary organization Föreningen för Israelsmissionen, which had been founded expressly in order to convert Jews to Christianity.

149 Abraham Capadose, Drag ur den portugisiske israeliten doctor Capadose's lefnads-historia: af honom sjelf berättade (Stockholm: N. Marcus, 1857).

150 David Baron, Judefrågan och dess lösning eller Israels nutid och framtid (Stockholm: Föreningens för Israelsmission förlag, 1898). 
At the end of the nineteenth century, conversion themes could also be used as a way to debate different issues. The pamphlet Den bortrövade judeflickan (1892) is mainly directed against the Salvation Army, which is said to have stolen a girl from a Polish-Russian-Jewish family in Helsinki and to have hidden her from her parents and the police until she could be baptized. To the extent that the girl's Jewishness plays a role in this tale of the Army's evil deeds, it is that she is said to have "utbildad judetyp" (fully formed Jewish type). This is reinforced on the cover of the booklet, which shows the profile of a girl with black hair, slightly bulging eyes, and a stereotypically large crooked nose. The Christian religion is said to have been "foreign to her and hated by her and her family." Within this story of abduction and forced conversion, Jewishness is described as a race, the girl's baptism the necessarily incomplete assimilation to a foreign culture and religion. However, the main line of criticism is the abduction and hiding of the girl, not so much the question of whether baptism really changes the Jewish essence.

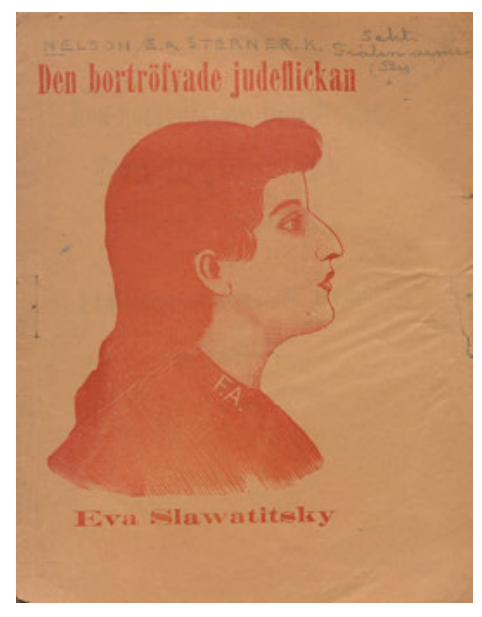

Fig. 5: Title page Den bortröfvade judeflickan Eva Slawatitsky (Kungliga biblioteket, Stockholm).

Towards the end of the century, Christian proselytizing to Swedish Jews became an actual project, and more and more converts published their memoirs and became lay preachers themselves within Föreningen för Israelsmissionen; for example, Henrik Steen, ${ }^{151}$ Nathanael Rosenthal, ${ }^{152}$ Philippus Gordon, ${ }^{153}$ and

151 Besides a number of textbooks on Christianity for children, Steen wrote Israels framtid enligt Gamla Testamentet (1904) and Jesu ställning till judafolkets nationella messiasförhoppningar enligt synoptikerna (1910).

152 Nathanael Rosenthal, Min omvändelse från judendomen till kristendomen (Hedemora, 1885). 
Isak Nathanael Sapira. ${ }^{154}$ Their autobiographical texts have so far mainly been discussed from the perspective of the Pietist and evangelical circles in which their conversions occurred: the reasons for conversion are discussed, as are the people and organizations arranging their post-conversion activities. Per Hammarström has observed that the narratives follow Pietist and Herrnhutenist traditions and models, and that the patterns of searching, crisis, grace, and salvation follow "nådens ordning" (the Order of Grace), a common form of lay didactic and catechetical guidance in Swedish Low Church groups of the period. ${ }^{155}$ But they can also be analysed within the context of anti-Jewish print production, written for and read by a public which was already familiar with religious and political polemics, narratives, and jokes about Jews. The texts not only function within the context of Pietist conversion propaganda, but also within the context of a society which had only granted Emancipation to Jews after decades of heated conflict. It is also worth noting that these texts and, more generally, the series published by Föreningen för Israelsmissionen, were the main factor behind the increased number of published works on Jewish themes towards the end of the century, when the production of political pamphlets about Emancipation had basically ceased and the publishing of legends and novels continued at the same rate as before.

The religious reservations about Judaism played out in the converts' texts as well. Jews were portrayed as stubborn and blind, Judaism and Jewish families as strict, loveless, and law-bound. Furthermore, the migration history of the converts, most of whom came from Eastern Europe (Poland, Lithuania, Russia this applies to the migration of the last three decades of the century, not earlier), was noted, and this added to the impression of Judaism being strange and foreign. Additionally, the Orthodox Judaism prevalent amongst these immigrants was already conducive to Othering, and the stereotypes derived from this affected even the Reform or assimilated Jews from other areas, as well as those who had already been in Sweden for several generations. Supersessionism was also a factor, and the individual conversions which were enthusiastically celebrated in

153 Gordon wrote a number of texts which were published in the series Skrifter ur Svenska Israelsmissionen, amongst them Jom Kippur: En berättelse ur det judiska folklifvet. Öfvers. från tyskan af Teodor Lindhagen (Stockholm, 1897), in two editions.

154 Isak Nathanael Sapira, Jude och kristen: Erfarenheter såsom jude och kristen upptecknade (Stockholm, 1892).

155 Per Hammarström, “Omvändelseberättelser, judemission och svensk lågkyrklighet runt sekelskiftet 1900," in Från legofolk till stadsfolk: Festskrift till Börje Harnesk, Skrifter från Institutionen för Humaniora 1, ed. Erik Nydahl (Härnösand: Mittuniversitetet, 2012); Per Hammarström, “Judiska konvertiter till kristendomen i Stockholm 1775-1870,” Historisk tidskrift 140 (2020). 
sermons, books, and legends led to the hope that the people of Israel would convert as a whole - a familiar Christian utopian-apocalyptic idea. In the converts' narratives, Judaism and Christian hostility towards Jews are a purely religious and cultural issue, while Emancipation and political and economic questions are left unaddressed. ${ }^{156}$

One of the reasons for this might be the fact that the German discourse is less prominent in this part of the corpus than in others; while translations from German do appear (Heinrich Jung-Stilling's Merckwürdige Bekehrungs-Geschichte), English and Dutch texts serve as the main models for popular post-medieval conversion narratives. Most notably so for the immense production of Swedish originals by people who immigrated from Eastern Europe but converted in Sweden and worked in a Swedish missionary context, which account for the majority of conversion narratives. This may have contributed to the lack of enthusiasm for questions of conversion in the parliamentary and political discourses in the country.

\section{Supersessionism and proto-racism}

The broad range of supersessionist thought and arguments laid a basis for racist or proto-racist arguments. As shown above, medieval text models established Jews as a group with specific fixed physiological and psychological characteristics. Conversion narratives added to the idea of Judaism being partly character-

156 One text in particular suggested supersessionism without actually arguing in that direction. Judendom och kristendom. Ett verk af gudomlig vishet (Stockholm, 1817) is a 130-page translation of "Philosophy of the Plan of Salvation. A Book for the Times. By an American Citizen," by James Barr Walker, a Presbyterian preacher, editor, and writer who would - 15 years after the first English edition of his book - become a professor at Wheaton College, Illinois, a private evangelical liberal arts college. To this day, the book continues to be printed, translated, and published in evangelical circles. There is even an audiobook version available on YouTube. As previously mentioned, the title "Judaism and Christianity" is misleading; Barr Walker argues for the general human need for religion, for the necessity of the development of monotheism, and the historical necessity of the period of Egyptian slavery for the people of Israel. The latter is used as a pedagogical example for Christian salvation: God punished the Jews in Egypt because of an incorrect development of their faith and service, and this should teach Christians a lesson. The period of exile is said to have done important things for the Jewish people regarding their national identity, their faith, and relation to God. Other aspects of the Hebrew Bible are also used as models for a desirable Christian development: a concept of holiness (chapter 7) and concepts of justice and mercy (chapter 8). Conversion is discussed in the book but only in the sense of Christians' conversion to a Christian life. Even the much longer English original, which ends with a number of examples of converts, does not contain a Jewish example. 
ized by ancient, incomprehensible, and meaningless rules and laws, partly corrupted by the evil of the deicide. These aspects were brought together in texts from various authors, writing in different countries on different topics, targeting Judaism as a religion and, as a result, also targeting Jews as a collective religious Other.

An early example that brought these aspects together in a distinctively racist combination appeared in the annus horribilis 1815. In some ways, it can be seen as related to the judefejden of that year; in others, it is more remarkable because it combines so many different anti-Jewish aspects, going far beyond the immediate issues at hand. Besides "nation" and "state," even "race" is used as a collective term (p. 22) - its application to the Jews may even be one of the earliest examples of this term being used in this way in Swedish. ${ }^{157}$

The title was Om judarnas företräde, välde och lycka (On the benefits, dominion, and luck of the Jews); it was published anonymously but was later attributed to Carl Gustaf Nordforss, whose contribution to the public controversy around granting Jews more rights in Sweden was to pen a satirical fictitious dialogue between a Catholic bishop in Venice and a rabbi. ${ }^{158}$ The idea of Jews as an unchangeable race with unchangeable characteristics is central to the text, which employs religious, cultural, and legal arguments.

Following a career in the military and the upper echelons of public administration, Nordforss had been appointed to the vice-directorate of the Dramatiska Teatern in 1799 and then to the Stockholm opera. In this capacity, he staged, wrote, and translated a number of plays and operas, becoming the important voice of a conservative artistic school and introducing a collection of conservative French composers to a Swedish audience. ${ }^{159}$ In its first edition in 1815, the satirical dialogue Om judarnas företräde was also falsely presented as a translation, which must be considered an attempt to lend legitimacy to the text by pre-

157 SAOB, lemma "ras, subst.2": "större grupp av individer hörande till en viss biologisk art, som uppvisar vissa gemensamma biologiska, ärftliga egenskaper, varigm den skiljer sig från andra grupper av samma art, o. som bildar en på olika sätt fixerad, ofta tämligen obestämt avgränsad enhet inom arten; grupp av biotyper med vissa gemensamma egenskaper l. med viss genomsnittlig ärftlig konstitution; ofta abstraktare, med tanke på det slag l. den typ av individer 1. de egenskaper som en sådan grupp representerar. Ren, oblandad, blandad ras.” SAOB finds that the first use of the word in this way was in 1818, earlier uses pertaining to the field of animals and plants and race as "om dylik grupp av människor; stundom använt utan klar avgränsning från: folk, folkstam 1. dyl.” SAOB, Spalt R 324 band 21, 1956.

158 Carl Gustaf Nordforss, Om judarnas företräde, välde och lycka: samtal (Stockholm: Cederborgh \& Comp., 1815).

159 K. J. Warburg, “Nordforss," in Nordisk familjebok. Konversationslexikon och realencylopedi 19: Mykenai - Norrpada (Stockholm: Nordisk familjeboks förlags aktiebolag, 1913), 1283. 
senting it as if it were part of an international discourse. It is the only text about Jews in Nordforss's oeuvre - at least, the only one identified to date, since he used a number of different pseudonyms for his writings, and it is possible that others might still lie hidden in the vast number of publications from the year 1815. Nordforss was obviously both well respected and connected within Stockholm's cultural and academic circles at the time; he won prizes from the Swedish Academy for his poetry and was also published in various newspapers.

The two protagonists, a Catholic and a Jew, are spending an evening together in Venice. The bishop, in the hope of converting the rabbi, tries to convince the latter that the messiah has already returned. This meets with an arrogant monologue by the rabbi in which he states that the messiah's return simply means a period of power and wealth for all Jews, which had already begun. The bishop serves merely as an excuse for this monologue; he answers only very briefly at the end of the 25 pages. In several subchapters, the rabbi argues that Jews actually enjoyed a better position in contemporary societies than Christians, concluding with the well-worn argument that their religion and their "nature" made them a state within the state, a hostile one even, only profiting from their host, whom they despise and hate. "Juden förblifver jude in saecula saculorum." (The Jew remains a Jew for all eternity, p. 10). Jews are consequently called a "nation" in this text, even "den stora nationen" (p. 2). The rabbi opposes the granting of civil rights to Jews because this would require the fulfilment of civil duties, and Jews are quite content to not work with their hands or on the land but to instead own factories and farms. Subchapter 13 is of interest regarding religion: here, the rabbi describes religious tolerance as something that only works for other religions, while it would be wiser for all societies to force Jews to convert, because the problem is not that they are of a different religion but that their religion commands them to be hostile to others (pp. 23-14). The motif of Jewish hostility appears several times in the text, the rabbi claiming that it is grounded in the Jewish holy books, as is the injunction for Jews to not mix with other peoples but to form distinct and hostile societies within their host societies - "en stat inom staten" (p. 8). While the holy book which commands hostility is not named, this is a direct but somewhat muted reference to the medieval and early modern attempts to ban and burn the Talmud, simply because of the hostility it was said to contain against Christians. ${ }^{160}$

160 See Jonathan Adams and Cordelia Heß, "Jewish Life and Books Under Scrutiny: Ethnography, Polemics, and Converts," in Revealing the Secrets of the Jews: Johannes Pfefferkorn and Christian Writings About Jewish Life and Literature in Early Modern Europe, ed. Jonathan Adams and Cordelia Heß (Berlin: De Gruyter, 2017); Robert Chazan, "Trial, Condemnation, and Censorship: The Talmud in Medieval Europe," in The Trial of the Talmud: Paris, 1240, Medi- 
Nordforss does not stop there. Even Jewish virtues can be traced back to a basis in vice: they do not drink because they are afraid they might tell someone their secrets, they do not fight because they are cowards (pp. 27-28). Whereas other people change throughout history, Jews have an eternal plan: to steal from Christians (p. 29).

There is only one explicit reference to Sweden: the rabbi says that members of various nations, "även Indianer," have moved there and that their children and grandchildren have merged with the population and have become Swedish, quite unlike the Jews (pp. 8-9). "En evig oförblandande, en evig ovandelbarhet" (an eternal non-mixing, an eternal inability to change), are presented as the essential characteristics of the Jewish people - there are even allusions to the Eternal Jew and the Ahasver legend. Implicitly, however, many of the arguments refer to the Swedish situation: for example, the fact that the judereglemente allows Jews to enter business and trade without the otherwise mandatory apprenticeships - only, the text suggests that Jews enjoy this privilege around the world (p. 15).

The rabbi employs several metaphors and biblical references in order to illustrate the relation between Christians and Jews. Jews are "the king in the chess game" (p. 12) because all the other pieces work to defend them. Jews are Jacob, while Christians are Esau, because Christians serve in most Jewish households and Jews do not work in physically demanding professions, unlike Christians (p. 11). (The rabbi seems uncertain about where this reference fits into Genesis, hinting towards his lack of religious education.) Jews were already dancing around the Golden Calf at the foot of Mount Sinai and are still mainly interested in gold (p. 19). The eternal essence of Jewish evil and the eternal presence of a Jewish secret plan are illustrated by the biblical story of Haman, in the Book of Esther, who was able to see through the Jews' plans to take over the Persian city of Susan, just as they dominate some capital cities in Europe today. This story is used for a several-pages-long exposition of how and why Jews are plotting to take control of European cities (pp. 30-35). The biblical allusions therefore cover all the main non-religious stereotypes: Jewish dominance and conspiracy, greed for money, and hatred of Christians, forging yet another connection between religious and other forms of hostility.

Kristendomen, dess uppkomst, dess lära, dess historia och dess utveckling jemte judendomens historia och litteratur. Efter nyaste forskningar utarbetad för

aeval Sources in Translation 53, ed. John Friedman, Jean Hoff, and Robert Chazan (Toronto: Pontifical Institute of Mediaeval Studies, 2012). 
folket af Nils Lilja ${ }^{161}$ presented Judaism and Christianity with the familiar theme of the one replacing the other. In the introduction, the author displays a distinctly racist worldview: "Den kaukasiska eller hwita folkstammen är den senast tilkomna och mest intelligenta race, den enda som betydligen uppträdt och werkat i werldshistorien [...]" (The Caucasian or white tribe is the most recently developed and most intelligent race, the only one of significance to have appeared and to have had an influence on world history, p. 4). Since the "white race" is said to be the creator of all religion and culture, at least Jews are subsumed as white, even though their contribution to world history is relegated to the distant past. The chapters dealing with Judaism basically paraphrase the Pentateuch then present a short and popular history of the people of Israel in the Egyptian, Persian, Greek, and Roman Empires, up to the destruction of the Second Temple. Nils Lilja, the author of this educational work of religious history, was a botanist, but he was not the only one to use the vocabulary of the emerging racial sciences in order to describe the relation between two of the major monotheistic religions.

\section{From Meiners to Nordmann: foreign antisemitism translated}

Svåra bevis emot judarna. Ur Meiners afhandling über den Handel und die Gewerbe der Völker des Mittelalters ${ }^{162}$ is a translation of a text that does not explicitly deal with Judaism as a religion, but which nonetheless draws a connection between the religious and economic aspects of hostility. The subtitle describes it as a translation of a German dissertation, but provides the incorrect title: volume 2 of Christoph Meiners's work Historische Vergleichung der Sitten und Verfassungen, der Gesetze und Gewerbe, des Handels und der Religion, der Wissenschaften und Lehranstalten des Mittelalters und denen unseres Jahrhunderts in Rücksicht auf die Vortheile und Nachtheile der Aufklärung was its model. The translation follows the model word for word, from pages 19 to 27; only one paragraph at the end, regarding the decline of trade in connection with a general decline in morals, is omitted. Footnotes and references are also translated. The only truly original contribution by the Swedish translator or editor is the title: "Hard evi-

161 Kristendomen, dess uppkomst, dess lära, dess historia och dess utveckling jemte judendomens historia och litteratur. Efter nyaste forskningar utarbetad för folket af Nils Lilja (Stockholm, 1860).

162 Christoph Meiners, Svåra bevis emot judarna, ur Meiners afhandling über den Handel und die Gewerbe der Völker des Mittelalters, trans. Lorenzo Hammarsköld (Stockholm: Fr. Cederborgh \& comp., 1815). 
dence against the Jews." Svenskt översättarlexikon attributes this translation to Lorenzo Hammarsköld, ${ }^{163}$ a Neo-Romantic translator, writer, and poet. It is unclear whether he was also responsible for the relatively unwarranted title. Indeed, the pages from Meiners's work do contain a diatribe in which Jews are blamed for the catastrophic state of commerce and moneylending throughout the entire Middle Ages. ${ }^{164}$ But this is based on the selective choice of pages to translate - just before, Meiners writes about the splendid business practices of the Hanseatic League and the excellent conditions for trade in the Netherlands, ascribed to liberal immigration laws and freedom of religion. Even though Meiners is today granted the title of "inventor of racism," 165 the work in question does not claim that the entire Middle Ages were devoid of functioning trade practices, just to blame Jews for this state of affairs. But this is exactly the impression the Swedish excerpt gives: that Jews had plunged Christian Europe into misery, from Carolingian times to the Reformation. This timeframe suggests that the Catholic period in general was a period of decay, and the fact that Meiners also blames the ecclesiastical elites in Italy for practising usury, which they had learned from the Jews, additionally combines anti-Judaism with anti-Catholicism. In this way, yet another historical period is used to conflate religious and other forms of difference regarding the Jews.

Also in 1815, an anonymous translator reproduced eight pages from the many volumes of Tobias Smollett's History of England, titling it Berättelse, huru judarne äro ansedda i England. ${ }^{166}$ At first sight, neither the title nor the original text model suggests anything to do with the Jewish faith. The publication examines the circumstances surrounding the 1753 "Jew Bill," which would have granted the British parliament the power to naturalize Jews. According to

163 Ludvig Berggren, “Lorenzo Hammarsköld, 1785-1827,” in Svenskt översättarlexikon, https:// litteraturbanken.se/översättarlexikon/artiklar/Lorenzo_Hammarsköld.

164 Christoph Meiners, Historische Vergleichung der Sitten und Verfassungen, der Gesetze und Gewerbe, des Handels, und der Religion, der Wissenschaften, und Lehranstalten des Mittelalters mit denen unsers Jahrhunderts: in Rücksicht auf die Vortheile, und Nachtheile der Aufklärung (Hannover: Helwing, 1793).

165 Peter Aufgebauer, “Christoph Meiners. Ein Göttinger Philosoph erfindet den Rassismus,” in Entdeckt, Erdacht, Erfunden: 20 Göttinger Geschichten von Genie und Irrtum, ed. Teresa Nentwig and Katharina Trittel (Göttingen: Vandenhoeck \& Ruprecht, 2019).

166 Tobias George Smollett, Berättelse, huru judarne äro ansedde i England. Öfwersatt från medicine doktor T. Smollets historia (Stockholm: Fr. Cederborgh \& comp., 1815); [Tobias George Smollett], Continuation of the Complete History of England; 5 vols (London, 1763-65), also known as The History of England from the Revolution to the Death of George II (designed as a continuation of Mr. Hume's History); vol. 2. For more about Smollett, see https://www.ne.se/uppslagsverk/ encyklopedi/lång/tobias-smollett. 
Smollett, the bill passed easily through the House of Lords but met with resistance in the House of Commons and amongst the population. ${ }^{167}$ The bill had to be revoked less than a year after its approval, and Smollett gives a detailed description of the arguments and emotions of the members of parliament and of the population who were against the bill, as well as the steps taken to revoke it. This part is surprisingly detailed, providing the names and positions of various lords and ministers. Specific parts of the bill which were deliberated upon at different times are also discussed; for instance, the role of a constitutional amendment which granted naturalization to Jews who had been living in a British colony for more than seven years, which was also revoked due to popular protests. Smollett himself - both in the English original and in the Swedish translation - clearly disapproves of the arguments against the bill, which he portrays as overly emotional. But he argues from a supersessionist position, and his words regarding the Jewish faith are harsh and biased: useless, wrong, hardened, blind. He states that the Jews will convert in the Last Days in order to be reunited with their creator but are to live homeless and wandering amongst the nations until then (p. 6). His clearly expressed hope was that once Jews were given the possibility of naturalization, they would abandon their "öfvertro" (superstition, p. 7). Besides the eternal wandering, which might be remedied by naturalization followed by conversion, Smollett sees parsimony as a distinctly Jewish feature, which helps them to offer products for cheaper prices and thereby take over branches of business - whether this is a part of their character, or whether it is something that could be remedied by conversion, is not made clear. Besides the usual fears of economic dominance, the possibility is discussed that Jews might be able to buy jura patronatum, and thereby gain power over Christian ecclesiastic matters - a possibility already precluded before the entire bill was revoked. Smollett instead suggests that the influx of economically powerful Jews would help the British economy, and that the problems of integration would simply not occur, because the Jews would automatically realize the truth of the Gospel.

With hindsight, this text almost seems to predict the revoked Swedish Emancipation bill of 1838; in fact, it seems that the parliamentary proceedings were of more interest to Smollett and his anonymous Swedish translator than the actual arguments against naturalization. Within the corpus, this is one of only two texts dealing with British relations, the other being Cooper's sermon for the conversion of Jews. It qualifies as a text with a primarily religious theme because the

167 See Dana Rabin, “The Jew Bill of 1753: Masculinity, Virility, and the Nation,” EighteenthCentury Studies 39, no. 2 (2006). 
Jews are exclusively seen as a religious community, the chosen text sample focuses on religious arguments, and, for the most part, the author's hostility towards Jews stems from supersessionism - most of his concerns regarding Jewish misdeeds will be dealt with, he suggests, once they have all converted.

In July 1818, some anonymous pages were printed in the Oppositions-Blatt oder Weimarische Zeitung under the title "Ein Sohn Israels an seine Brüder."168 That same year, a close translation was published in Sweden as an independent and similarly anonymous 14-page pamphlet, with a subtitle and a hint that the original was in German. No editor's or translator's preface, however, provided any indication as to where the text came from or why it had been chosen for translation. It is a subtle but mean-spirited text, suggesting that if the Jews had been held in captivity and slavery for more than 2,000 years, despite having behaved more like lords than slaves in their host countries, it was up to them to put an end to their bondage. The solution, presented in the last third of the text, would be to conquer the land of Israel. En son Israels till sina bröder bases its argument on the idea of an eternal, never-changing collective Jewish character. It is written from a mock Jewish perspective, in the first person plural, and is addressed to "my/our brothers." While the author does not dismiss cultural determinism, which holds that a people's character is determined by its surroundings, Jews are presented as an exception, resistant to changing their collective character even though they live in so many different places. "Hvarken Nordens köld eller den tropiska solens hetta har kunnat förändra vår National-caracter.” (Neither the cold of the North nor the heat of the tropical sun have been able to change our national character, p. 1). All other ancient peoples have disappeared, the Jews are the only "eternal ones." These eternal Jewish characteristics help them to win in all wars yet prevent them from benefiting from universal human rights. The text connects contemporary Jewry with the biblical people of Israel. It alludes to the story of Ezra, who rebuilt the temple, and appeals to Jews to go back to the Holy Land. But since they are not wanted there, they will first need to learn to fight, preferably in the German armies. Since all the European countries would be happy to be rid of them, they would support the formation of a Jewish army, sell them weapons and supplies, and help them to learn military techniques in order to successfully fight the Turks. Jews would want to put an end to the current period in which they only "tära och drage vinsten af andras arbeten" (eat and reap the benefits of others' work,

168 Anonymous, En son Israels till sina bröder: en anmaning till judarna att åter inkräkta det förlofvade landet: ifrån tyskan (Stockholm: Elmén och Granberg, 1818). 
p. 13) through trade and usury. The Lord's wrath will not last forever, and the Jews can put an end to their exile if they want to (p. 14).

Towards the end of the century, another text appeared in which a Jewish exodus from Europe was suggested, in a similarly satirical form and also with a presumed Jewish speaker. Here, too, Judaism was itself presented as the source of the problem. In Råd till judarne / från tyskan ${ }^{169}$ the ongoing migration from Western Europe to recently independent Argentina was portrayed as an attempt to form an entirely German-Jewish colony. In a spiteful tone, descriptions of everyday life in Buenos Aires were mixed with calls to convince economically powerful Jews to organize the mass migration. Printed in Stockholm in 1882, this text strangely anticipated the formation of the Jewish Colonization Association by Baron Maurice de Hirsch, even though this organization mainly assisted Eastern European Jews in reaching Argentina from 1889 on.

Older text models were also used in Sweden to portray Judaism as a vile religion. In the German lands, a combination of ethnographic and linguistic studies had emerged which purported to expose the presumed secreta Iudaeorum, while also continuing the medieval tradition of using Jewish texts to "prove" that Jews were wrong. A prominent example was the two volumes of Johann Andreas Eisenmenger's Entdecktes Judenthum. These had been subject to an attempt to prevent their publication in the Holy Roman Empire due to their hostile content, but they appeared posthumously in 1740 in Königsberg. Eisenmenger used quotations and translations from rabbinical texts, combining and interpreting them in such a way as to support longstanding anti-Jewish ideas: that hidden in the rabbinical texts and the Kabbalah was a secret Jewish plan for world domination, political intrigue, and turmoil, as well as general abuse of Christians. There are uncorroborated claims that Eisenmenger pretended to be a convert in order to be able to learn from Jewish scholars; in the end, he spent 19 years searching through rabbinical writings in order to "expose" the secret plan. ${ }^{170}$

The Protestant theologian Christian Frank took Eisenmenger's Entdecktes Judenthum from 1700 and prepared a 90-page abstract from it, adding no really original material - because, as Frank notes in his introduction, very few people were as qualified as Eisenmenger, a professor of Hebrew knowledgeable in Oriental languages, to unlock the secrets of rabbinical texts. In 1822, a translation of

169 Anonymous, Råd till judarne / från tyskan (Stockholm: H. Lindgren, 1882).

170 Bjoern Weigel, "Eisenmenger, Johann Andreas," in Handbuch des Antisemitismus, vol. 2.1, 200-1. 
Frank's book Die Juden und das Judenthum, wie sie sind was prepared in Sweden and published in Linköping, six years after its original publication in German. ${ }^{171}$

The major part of Christian Frank's book consists of selections from the translations and quotations of Entdecktes Judenthum. In a similar vein, Frank collected and combined quotations out of context in order to "prove" the existence of a Jewish conspiracy to overthrow the governments of Christian states. The quotations themselves are real, but their lack of context and their selection from anti-Christian polemics simply serve to portray all Jewish texts as generally hostile. The introduction clearly states the purpose of the entire project: to move secular leaders to "protect" their territories by expelling the subversive Jews.

So the Swedish translation is a reworked version of an abridged, reworked version of an early eighteenth-century selection of cherry-picked quotations from a collection of rabbinical texts - but it purports to be a presentation of faithful translations of quotations from the Talmud. It is structured around five subtopics: What do Jews teach about other peoples? What do Jews teach about the Christians? Various aspects of Jewish ethics. What do Jews teach about God? What do Jews teach about the soul?

The introduction, however, must have been written by an anonymous author or the anonymous translator, as it is different from the introduction by Frank. The Swedish writer expresses his fear that despite the fact that Sweden had yet to experience a major Jewish influx, caution is warranted because of what Jews might do to the country in the future. The book is therefore an attempt to prevent the liberalization of restrictions for the Swedish Jewish minority, its argument based on timeless Jewish writings with the idea being: if they have been this cruel before, they will be so forever. Explaining why the work was translated, the introduction refers to the role of the Jews in the current repression of Greeks in the Orient, which is described as a warning written in blood. Jews do not feel bound by any social commitments. The term "fremde Glaubensgenossen" (foreign brothers in faith), which had become popular in Germany, was introduced in order to cover up the expression of their national character in the Orient. In its wisdom, the Swedish government has prevented a "Jude-intrång" (Jew-invasion) so far, but no one knows what the future holds: various potential threats Jews might pose in the future are imagined, particularly threats by rich Swedish Jews, with constant references to the "Jewish character" (p. 4). Here, too, the hope is voiced that in the course of a national awakening, Jews will be expelled to the Holy Land. "Utan fädernesland, utan Landsmän (sådane se

171 [Christian Frank], Judendomen, framställd utur de rabbinske skrifterna, såsom en fiende till christendomen och den rena sedligheten (Linköping: Petre och Abrahamsson, 1822). 
de blott bland sig sjelfwe) äga de inga andra förhållanden till oss än egennyttans, - utwecklade ofta på scandalöst sätt.” (With no fatherland, without fellow countrymen (these they are only to themselves), they have no relation to us other than self-interest, developed in a scandalous form, p. 6). Christians have to work for the Jews. They are lords, "we" are servants. The introduction is a logically incoherent, fiercely hostile screed against all Jews, while also describing Sweden as being free from the problem, though in danger nonetheless. The expressed opposition to the term "Glaubensgenossen" while simultaneously mentioning Jewish "national character" indicate that the author wants to argue against a religious, and in favour of a national, essentialist, and biological, definition of Jewishness. References to the German lands help to position the translator politically: he mentions Frankfurt and Lübeck as good examples of places that rid themselves of Jews, and he names a particular text as an exemplar of Jewish rottenness: Philipp Wolfers's "Aufruf an alle edeldenkenden Israeliten" from 1821. Wolfers (1796-1832), a Jewish physician, had published a number of texts in which he argued for medical control of circumcision and for the establishment of Jewish pedagogical institutions. ${ }^{172}$ While the false suggestion that Lübeck and Frankfurt had expelled their Jewish communities seems ungrounded (at least for this period), the singling out of Wolfers seems to point in the same direction as the "Glaubensgenossen" argument: Jews who advocate assimilation into Christian societies and improved living conditions and educational opportunities for Jews are particularly dangerous. This introduction, combined with the quotations from rabbinical texts, portrays Jews as an eternal danger to Christian societies, shaped by their ancient laws demanding hostility, and putting these into practice wherever they settle.

The publication of Judendomen, framställd utur de rabbinske skrifterna is significant in several regards. First, it reveals an interest in Christian-Jewish relations in the German areas and an early attempt to adapt the German texts for a Swedish public - even though the situation was entirely different in Sweden. By adding a new introduction addressing Swedish realities, the translator suggested that the "Jewish danger" was also present in the North, or at least soon would be. Who might have been the intended audience for this book? The inclusion of German names and texts, without further comment, suggests an audience well versed in German anti-Jewish discourse. The featured "rabbinical writings" connect it to a centuries-old fascination with the secreta Iudaeorum, which can

172 Arno Herzig, "Das Assimilationsproblem aus jüdischer Sicht (1780-1880)," in Conditio Judaica: Judentum, Antisemitismus und deutschsprachige Literatur, ed. Hans O. Horch and Horst Denkler (Tübingen: M. Niemeyer, 1988), 23. 
largely be traced back to Johannes Pfefferkorn in sixteenth-century Cologne. Finally, the focus on both Jewish religious and biological features meshed with racist arguments against an emancipated and assimilated Jewry, the likes of which did not exist in Sweden.

In contrast to many other anti-Jewish texts, the book provoked a response from "S. P.," most likely a member of the small Jewish community in Sweden. ${ }^{173}$ This indicates that the attempt to use Jewish sources to prove Jews evil was felt to be more dangerous than most other strategies to defame Jews - at least, it had a long historical tradition, from the burning of the Talmud in Paris in the thirteenth century to Johannes Pfefferkorn's book-burning campaigns. The response, Några ord om den skandalösa brochuren Judendomen, argued that the rabbinical texts in question were very old and of essentially no significance to contemporary Jews and their religious teachings and, furthermore, that certain historical relations between Jews and Greeks were inaccurately portrayed.

The German lands continued to provide fresh products of antisemitic writing; as in previous cases, the Swedish Jewish community was most concerned about those which claimed to use Jewish texts to prove Jewish hostility. In 1822, Friedrich Buchholz's Judarne i verldshistoriskt afseende ${ }^{174}$ was published. Buchholz's previous book, Moses und Jesus oder über das intellektuelle und moralische Verhältnis der Juden und Christen. Eine historisch-politische Abhandlung (1803), already painted a detailed and highly negative picture of the religious foundations of Judaism.

Buchholz's attitude towards Jewish Emancipation was complicated. He had co-authored the Hardenberg Edict of 1812 and protested against the use of his texts in the Danish antisemitic debate, ${ }^{175}$ but his works that were translated into Swedish are clearly hostile. He was not only a prominent intellectual in Sweden, he was also an important influence on the fathers of Norway's constitution of $1814 .{ }^{176}$ He saw not just Jews, but also Christians, as eternal groups, within which each "fully developed" individual displayed certain characteristics - in the case of the Jews, selfishness and particularism, in the case of the Christians,

173 Anonymous, Några ord om den skandalösa brochuren: Judendomen, framställd utur de rabbinska skrifterna såsom en fiende till christendomen och den rena sedligheten (Carlskrona: Flygare, 1822).

174 Friedrich Buchholz, Judarne i verldshistoriskt afseende (Stockholm, 1822).

175 See Iwan-Michelangelo D’Aprile and Håkon Harket. "Constitutional Discourse and Anti-Judaism: Friedrich Buchholz and Christian Magnus Falsen," in The Exclusion of Jews in the Norwegian Constitution of 1814: Origins - Contexts - Consequences, ed. Christhard Hoffmann, Studien zum Antisemitismus in Europa 10 (Berlin: Metropol, 2016).

176 Harket, Paragrafen, 379-80. 
selfless contributions to the general development of humanity. Those individuals who did not fit into this framework were not fully developed, he claimed, employing an essentialist understanding of populations and their collective character traits - what some decades later would be known by the term "völkisch." While Buchholz himself shifted his opinion after 1809, towards favouring Emancipation as a way to eventually get rid of Judaism, the Swedish translations functioned within the contemporary debate as statements against any possibility of integration. The translation of Buchholz's anti-Jewish texts occurred at the same time as the translation of some of his later liberal-democratic writings about the European states after the Napoleonic wars - after all, Buchholz's political agenda was not only antisemitic, it was also liberal, proto-socialist, and directed against the nobility. ${ }^{177}$ Another one of Buchholz's antisemitic texts was translated and published anonymously in two parts, as a contribution to the 1815 judefejden. ${ }^{178}$ Lurifaxiana was a compilation of several of Buchholz's statements regarding Jewish history and rituals being signs of an inferior culture. It also contained excerpts and translations of Jewish texts and terms, suggesting that their laws commanded Jews to betray Christians, to not keep their oaths to Christians, to exact revenge against converts, etc. The two parts of the booklet provoked a response from Heinich Heilborn, a Jewish immigrant, who not only criticized the content but also the faulty translation of Hebrew terms and concepts. ${ }^{179}$

Other texts by Buchholz were combined with Friedrich Rühs's Über die Ansprüche der Juden auf das deutsche Bürgerrecht and published as Judarnas Chrönika (in two parts) in $1822 .{ }^{180}$ Containing no indication of year or place of publication, Jakob Friedrich Fries's commentary on Rühs's pamphlet, titled Über die Gefährdung des Wohlstandes und Charakters der Deutschen durch die Juden (published in German in 1816) was also issued in Swedish. ${ }^{181}$ Fries's text, while based on religious arguments, anticipated several proposals that would later be associated with racist antisemitism: he advocated expulsion or emigration, compared Jews to animals, and advocated the need for distinguishing marks. Fries argued against any Jewish presence and for a religiously homo-

177 Werner Bergmann, "Buchholz, Paul Ferdinand Friedrich," in Handbuch des Antisemitismus: Judenfeindschaft in Geschichte und Gegenwart, vol. 2.1.

178 See also the Introduction.

179 Heinrich Heilborn, Lurifalsiana eller Den tilltvålade Lurifaxiana. Första och sista häftet (Göteborg: Sam. Norberg, 1815).

180 Friedrich Buchholz, Judarnas chrönika, 2 vols (Stockholm: Zacharias Haeggström, 1822). 181 Jakob Friedrich Fries, Om den fara, för hvilken vår välfärd och charakter blottställas genom Judarna. Ett bihang till Prof. Rühs'skrift om Judarna (s.l., s.a.) 
genous German nation-state $\mathrm{1}^{182}$ - an argument well suited to the Swedish debate and state.

In 1839, one year after the failed attempt to grant civil rights to Jews in Sweden, Ekmarck's printing house in Strängnäs published Jude-emancipationen by Ernst Wilhelm Hengstenberg, translated into Swedish by Eric Malmborg. ${ }^{183}$ The German original had appeared in 1837 in Evangelische Kirchen-Zeitung. ${ }^{184}$ Its title notwithstanding, this is not a discussion of Emancipation but a theological and exegetical treatise, and as such it qualifies as part of the discussion of supersessionism. Hengstenberg was a prominent advocate of supersessionism and of the typological model, which interpreted the Hebrew Bible, in its entirety, as a prefiguration of the Gospel. His opposition to civil and political rights for Jews was justified by religious arguments. ${ }^{185}$ While the idea of biblical prefiguration remains important in this text, it projects the idea that Christianity has rendered Judaism obsolete onto an abstract "Jew" while discussing Emancipation. Hengstenberg, while strongly opposed to Emancipation, concedes that it has already been realized and insists that he does not wish to withdraw the rights granted instead, his argument is that, regardless of whether they are granted rights, "the Jew" will remain the same and, regardless of their rights, "the Jew" will remain unfree because freedom is only possible through the Gospel. "Man emanciperar det som man icke kan göra fritt" (One emancipates that which one cannot free, p. 41). The only mention of the subject is the claim that, even if they have received civil rights, Jews participate only superficially in their duties towards the state because they are a "folk utan stat" - an interesting juxtaposition to the numerous "stat inom staten" statements.

Most of the text consists of theological explanations of Psalms and other parts of the Hebrew Bible. In some cases, these are brought in relation to contemporary Jews, whom Hengstenberg sees as entirely anachronistic - their previous virtue, monotheism, having been destroyed by the living God, and their having thus become alienated from the contemporary world, which is based on the Christian worldview and the Christian relation to God and the world. In terms of Jewish foreignness to the world, their relation to trade, craftsmanship, and ad-

182 Bjoern Weigel, "Fries, Jakob Friedrich,” in Handbuch des Antisemitismus, vol. 2.1.

183 Ernst Wilhelm Hengstenberg, Jude-emancipationen (Strängnäs: Carl Erik Ekmarck, 1839). 184 Ernst Wilhelm Hengstenberg, "Die Emancipation der Juden," in Evangelische Kirchen-Zeitung 20 (1837).

185 Regarding the conclusion of Hengstenberg's antisemitism, see Klaus Beckmann, Die fremde Wurzel: Altes Testament und Judentum in der evangelischen Theologie des 19. Jahrhunderts, Forschungen zur Kirchen- und Dogmengeschichte (Göttingen: Vandenhoeck und Ruprecht, 2002), 268-69. 
ministration is portrayed as entirely different from that of Christians in similar positions. For example, Jews could teach languages or work as craftsmen, but they could not become part of the Christian institutions - schools, guilds which imbued these professions with the right spirit. Hengstenberg recommends that within Christian societies, Jews only be allowed to do unskilled work, while they could become scholars and experts within their own communities. Conversion is not of much interest in this text: converts usually remain secret Jews out of loyalty to their forefathers (p. 14).

Hengstenberg gives detailed explanations of how the "Jewish character" derives from the relation between Jew, God, and law. It is heartless, greedy, false, and lacks honour (p. 13). "The Jew" consists of nothing but abstraction and individualism. With its extreme dualism, Hengstenberg's view fits very neatly into David Nirenberg's framework of the enduring characteristics of anti-Judaism: "the Jew" is presented as abstract, individual, law-centred, disconnected from the world; "the Christian" as concrete, communal, spirit-centred, loving the world. ${ }^{186}$

This text once again established a strong connection between religious and racial stereotypes, presenting the idea of a religiously grounded, unchangeable Jewish character as an argument in a contemporary political debate. What it proposed for Swedish Jewish-Christian relations was similar to what had prevailed in medieval Christian societies before and between outbreaks of violence: Jewish minorities being the barely tolerated, hated, and despised Other, who could be targeted for violence at any time because the violence could always be legitimized. Hengstenberg's politicization of biblical exegesis ${ }^{187}$ carried even more weight in the Swedish context, where the elimination of all non-Protestant religions might have actually seemed feasible.

Finally, in 1880, a translation of the ninth (out of thirteen) edition of Heinrich G. Nordmann's pamphlet Die Juden und der deutsche Staat appeared in Sweden. ${ }^{188}$ First issued in 1860, subsequent editions had been published by Theodor Fritsch in the context of the Berliner Antisemitismusstreit. The Swedish preface presents it as an important warning from another country, one where the Jewish influx was much further advanced and where people were more open about their negative feelings towards Jews. The anonymous translator ends his preface with, “Må gamla Sverige aldrig bli lika förjudadt som Tyskland!” The later chapters present what were by then well-worn arguments against Jewish equality and ac-

186 Nirenberg, Anti-Judaism, 1-13.

187 Beckmann, Die fremde Wurzel, 268.

188 [Heinrich Nordmann], Judarne och den tyska staten. Stockholm: Ulrik Fredriksons, 1880 (three editions, see appendix). 
cess to government and military positions, whereas the first chapter rehashes the somewhat illogical idea of Judaism as a contract between YHWH - "as a secular ruler" - and the Jews, from which the latter were supposed to receive benefits in a variety of secular fields (p. 6). Jewish law is described as a "constitution" (ibid.) and is thereby compared to the political and social order of a nation-state. Jewish religious feasts are said to simply be commemorating events in the history of the nation. Finally, in the conclusion, Judaism is not presented as a religion but as a race ("ras," p. 12, 14): initially constituted by religious laws, as a consequence of centuries of oppression it then turned into a racial type with a specific phenology and character, and as such encompassed both religious and assimilated Jews (p. 23). The entire pamphlet uses terms connected to race, argues against mixed-race marriages, proclaims a general hostility of the "Jewish race" towards the "Germanic race," and so on - the full scope of racist antisemitism being published in two editions in Sweden in 1880.

Besides these prominent examples of German antisemitic texts being translated into Swedish, Wilhelm Marr's Judarnes seger öfver germanerne betraktad från social och politisk ståndpunkt was also translated (Uppsala, 1881). As one of few texts in this corpus, it was also printed in Finland, in 1920 and 1921. ${ }^{189}$

\section{Conspiracy theories}

In 1846, a French text, written in the first person under the pseudonym "Satan," was translated into Swedish and published as En uppbygglig och sällsam historia om Rotschild I, judarnes konung (An edifying and noteworthy story about Rothschild I, king of the Jews). ${ }^{190}$ It introduced a very specific and distinctly modern conspiracy theory into Sweden: Nathan Rothschild, the successful banker and immigrant from Frankfurt am Main to London, was accused of having known the outcome of the Battle of Waterloo beforehand and of having manipulated the stock market accordingly, resulting in immense profits for himself. The author of this text was Georges-Marie Mathieu-Dairnvaell, a French socialist and writer who concocted this story in connection with his fears about the development of the railway system and the Rothschilds' investment in it - he also pointed to a train accident in 1846 as proof of its general dangerousness. In this mix of fear of modern transportation, Jew-hatred, and French national humiliation, the

189 See appendix.

190 Satan, En uppbygglig och sällsam historia om Rotschild I, judarnes konung (Stockholm: Elmén and Granberg, 1846). 
Rothschild family was presented as a group of conspirators secretly working to advance their own - and, more generally, Jewish - interests, well-connected through their financial affairs, and controlling secular rulers with their economic power.

This text did not introduce conspiracy theories to Sweden, it was just one text which made one very specific idea in this field very explicit. The broader idea that Jews conspired and acted in secret had been known since the Middle Ages and was transmitted in various texts, using religious differences as a vehicle and an argument. As a commentary on the ongoing riots and conflicts surrounding King Karl XIV Johan's attempt to grant Emancipation to Jews in Sweden in 1838, Johan Gustaf Hjerta wrote a spiteful and hate-filled pamphlet titled Omskärelsen eller den stundande tiden, published anonymously. ${ }^{191}$ The text suggested that the Jews were conspiring together with their friends to take power in Sweden and to judaize all Swedes.

Hjerta, who had been dismissed as a civil servant due to financial problems stemming from gambling debts, would in later years be a radical liberal publicist and writer. After being forced to close his radical liberal newspaper Medborgaren, which promoted a Christian socialism drawing on French models, ${ }^{192}$ Hjerta joined the editorial board of Aftonbladet ${ }^{193}$ - the daily newspaper which was most outspoken in its criticism of the king and Carl-Gustaf Skogman, and also the most openly antisemitic during the events of 1838 . With barely disguised references to the two advocates of the attempted Emancipation, Omskärelsen eller den stundande tiden comments on the situation in a way that combines religiously informed and framed antipathy with contemporary Jew-hatred. Circumcision is the leading theme of the text and is used as a metaphor for the idea that Emancipation will lead to Jews taking over and Christian Swedes being consequently forced to adapt to Jewish culture, religion, and business practices: "Då omskäras alla, alla" (then everyone is circumcised, everyone) is the dystopian ending of the rhymed text, and a reference to the "kringskuren kung" (circumcised king, p. 3) repeats the rumour - which was circulating in the country in 1838 - that Karl XVI Johan himself was Jewish. Besides circumcision, the names Nathan, Haman, Moses, and Levi, and even Judas Iscariot, are also used to refer the Jewish people as a whole, and these are juxtaposed with Swedish-Christian keywords: pepparkakor, Christ's cross, Christmas. The well-established connection between Jews and the devil is reinforced by names referring

191 Gustaf Hjerta, Omskärelsen eller Den stundande tiden (Stockholm: Nordström, 1838).

192 See "Medborgaren," in Nordisk familjebok, Uggleupplagan vol. 17, col. 1379.

193 Jean Göransson, "J Gustaf Hjerta,” in Svenskt biografiskt lexikon, https://sok.riksarkivet. se/sbl/artikel/13639. 
to the latter: Satan, Leviathan. In this text, Jewish wrongdoing consists of the attempt to "become like," and thereby take over, Christian society. Hjerta's fantasy accuses Jews of depicting themselves as bearers of Christ's cross, as prophets of the time when all Swedes will be circumcised, and as seducers of "poor girls" who might be tempted to marry a Jew and then have Jewish children - who will also be circumcised. The threat of circumcision, both literal and metaphorical, portrays Emancipation as a bloody procedure which involves a direct threat to harm all Christian Swedes. It is apparently the only text dealing with this core Jewish ritual to be produced in the entire century.

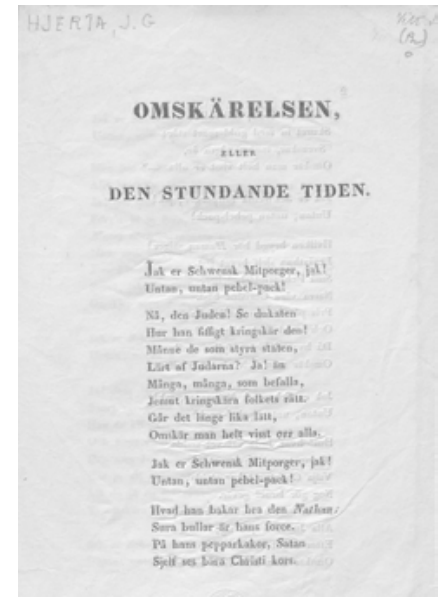

Fig. 6: Title page Omskärelsen eller den stundande tiden (Kungliga biblioteket, Stockholm).

Josef Linck, a conservative journalist who mainly wrote for the newspaper Vikingen, published two of his public speeches in Stockholm under the title Jude-frågan. ${ }^{194}$ He claimed that there was a war between the Jewish and the Christian races in which the former always strove to prevail economically over the latter. The racial differences, according to Linck, were visible in the completely distinct physiognomies, but they derived from the unconscious religious feelings which determine an individual's character - again, a religiously based argument that Jews not only constitute a race unto themselves but are also in a secret war against Christians. Linck's version of a broad conspiracy theory is explained in connection with "Jewish" business practices: owning land but not working it, profiting as a publisher from the intellectual work of others, etc. In this text, a racist conception of Jews and Judaism, a religious basis for this conception,

194 Josef Linck, Jude-frågan (Stockholm: Central-Tryckeriet, 1882). 
and the idea of "Jewish" business practices, all feed into the author's imagined "secret war" being fought between Jews and Christians.

\section{Judaism as the basis of the Jewish "race"}

Distinctly religious anti-Judaism was a prominent factor in the Swedish debate, as the print production shows. Rapidly developing German antisemitism provided the majority of text models, despite the very different political circumstances and make-up of the Jewish minority there. The text genres vary, though: En son Israels till sina bröder is written in the first person plural, creating the illusion of a sincere discussion amongst Jews. Ridicule and stereotypical attributions are woven into the text, subtly creating the impression that Jews not only know why they are so unpopular in Europe but that they also understand that the hostility derives from their distinctive characteristics. The close connection between the Israelites of the Hebrew Bible and contemporary Jews allows religious, political, and racial hostility to come together. The proposed solution, a kind of prototypical pseudo-Zionism, presents itself as a win-win situation for Jews as well as for European Christian societies. Addressing the Swedish situation in 1818, it says: You will never receive citizenship and human rights in Sweden. Even though you profit off of us with your business practices, you are in bondage and will remain so forever because you are different. Better to go back to Germany, learn to fight, and conquer a land of your own. To Swedish Christian readers, it conveys the idea that Jews are unwanted wherever they live, that they have a strong collective identity spanning the world, and that they know they are a burden to their host societies.

In part, the other texts seem to involve sincere political discussions about civil rights (Jude-emancipationen); in part, they seek to satisfy the Christian desire to know more about Jewish "secrets." They are interwoven with religious arguments against political Emancipation, and the Torah is used as a weapon against its own people. Even though the targets of these authors are Judaism as a religion and Jewish texts, political, economic and biologistic arguments are also invoked: for example, the idea of a Jewish world conspiracy, the construction of a "Jewish character" using quotations from the Hebrew Bible, and the ridicule of Jewish weakness and inability to fight in armies. The model texts from Germany (and, in one case, England) are supplemented with contemporary Swedish introductions, warning against the growing influence of rich Jewish immigrants.

Nordforss's text seems to have been quite successful: it had already been printed in a second edition in 1815 and was then reprinted in 1935 in the National 
Socialist publishing house Svea rike, a fact which adds to the impression that the text was ahead of its time regarding its ideology and language. It employs a powerful combination of religious, racist, and political stereotypes in which the idea of the Jewish religion being at the root of the hostility gives way to all the subsequent stereotypes. Conversion is closely associated with Emancipation, even though the main aim of the fictitious dialogue is supposedly conversion. Everything the rabbi says in this text bears a double meaning: it is true because it reveals secret knowledge about Jews and their conditions, which the bishop does not have; it is false because it comes from a representative of the false religion. As explained in the introduction, it takes place in Italy, where the warm climate makes people speak more openly. The dialogue seems both realistic and unrealistic, in part because the Christian interlocutor is Catholic, and the rabbi's arguments are therefore directed towards a representative of what Swedish Lutherans would view as the other false faith. This kills two birds with one stone: the Jew is presented as evil, cunning, and in control; the Catholic as a powerless, naïve listener who can provide no arguments against the Jew. The Catholic begins the dialogue wishing to convert the Jew but stands impotent and speechless at the end, incapable of doing anything but agree with the rabbi. The number and range of anti-Jewish stereotypes alluded to and discussed in the text point to an author well versed in the field. Even though it was his only text about Jews, Nordforss had access to a wealth of anti-Jewish (and anti-Catholic) knowledge.

It is difficult to understand how and why a historiographic study of the medieval economy would be used as "hard evidence against the Jews," or why Hammarsköld would choose the paragraphs about medieval Jewish business practices in order to prove that Jews had to be kept out of the Swedish Empire. One explanation lies in its year of publication: 1815, when Stockholm at least was entirely preoccupied by a flood of publications with Jewish (mostly anti-Jewish) themes. Another might be the fact that the historiographic argument added to the impression that Jews had always been a troublesome, foreign element. The simultaneous taunt against Catholics strengthened the argument that a religion that was not closely connected to the state could not foster loyalty and commitment from the population. Christoph Meiners's books were early arguments for cultural determinism and biological racism, and even though these categories did not make much sense in Sweden in 1815, the general idea of Jews being an unchangeable collectivity, who would always hinder the development of their host societies, contributed to the distinctively Swedish Frühantisemitismus.

Omskärelsen eller den stundande tiden goes one step further regarding fears of judaization. Christian fantasies about the core Jewish ritual brit milah are relatively rare in the corpus, but here, the fear of what Jews might do to Sweden is 
combined with fear of castration and even national castration - becoming Jewish as a result of Jewish dominance.

Jewish religion, faith, and law serve as the basis for anti-Jewish arguments in these texts, and this makes it possible to trace the development of the idea of Jews being an unchangeable group who follow their own laws, to the idea of Jews being a state within the state. Jews in the Swedish diaspora are an actual group who live according to different religious customs, and the experience of the diaspora has shaped Jewish communities for centuries. Furthermore, Christians claim that adherence to Christian law and ethics shapes their collective identity and behaviour to some extent, so applying the same principle to Jews is not unreasonable. But as Christianity is thoroughly enmeshed with the Protestant Swedish state and its laws, adherence to these can make it seem as if religion, identity, ethics, and civil law are all basically the same, or at least all derive from the same religious-ethical roots. For Jews, on the other hand, their adherence to religious law seems to mean following a set of rules developed in the Middle East several thousand years ago - Protestant Christians easily forget that their laws were also created in the same setting, and not by King Gustav Vasa.

In addition to this difference between Protestant states and the Jewish diaspora, and the respective relation between religious laws and civil laws, the Swedish (and German) text production about Judaism was inspired by other anti-Jewish knowledge as well. This led to rejecting the obvious similarities between Jewish and Christian religious texts and laws, and to a combination of supersessionism, religious hostility, and political hostility.

It is striking that all of the Swedish examples in which Judaism was targeted as such, as being either obsolete or hostile, were translations from English and German texts, some of them quite recent and some of them hundreds of years old. None was reprinted in a second edition, and they appear to have been far more prevalent in the first half of the century.

The existence of Swedish political antisemitism has always been denied. Indeed, no such institutions, parties, or organizations are visible in the nineteenth century. Yet, given the quantity and speed of translation and publishing of the key works of German antisemitism - in particular, both in the first two decades and in the last three decades of the century - the existence of a network or a pressure group of people orchestrating this seems likely. Translators were most often anonymous, and no single publishing house or town is obviously central to these productions - instead, the works of Meiners, Fries, Rühs, Marr, and other prominent German antisemites were evenly spread across the entire country. Considering the fact that most of the academic and administrative elite in Sweden was able to read German, the readership of these works, in both German 
and Swedish, must have been even more widespread than the translations alone suggest. It is difficult to identify direct intertextual allusions or other proof that the German arguments inspired Swedish authors to employ similar arguments but the fact that Nordforss was well acquainted with the basic arguments of racist antisemitism as early as 1815, having arrived at these positions through a religious line of reasoning, shows that external influences might not have been necessary for such ideas to develop in Sweden. Later in the century, both liberal and conservative journalists joined those who defined Jews as a race, as dangerous and at war against Christians - indeed, as winning the war. In the field of political and racist antisemitism, intertextuality and, consequently, shared features with other discourses are evident: printed books were included as inserts in newspapers, as articles or series; authors worked as journalists, scholars, or translators, giving public speeches which were then printed. As has been noted by Shulamit Volkov, in regards to the German Empire towards the end of the nineteenth century, antisemitism was not a question of political attitude but was a cultural code in which liberals, conservatives, and others mixed elitist and educational discourses. But there was a significant difference in Sweden, where anti-Judaism seems to have denoted a liberal political perspective, given that the conservative king was pro-Jewish. As such, the liberal position was to demand a popular vote, or at least the involvement of the Riksdag, in any legislation intended to relax the judereglemente. 